\title{
Poder e liturgia em The Godfather de Francis Ford Coppola
}

António Fidalgo

\section{Resumo:}

O filme "The Godfather" (intitulado "O padrinho", em Portugal, e "O poderoso chefão", no Brasil) é um filme de "gangsters", de uma família mafiosa, de um poder constituído fora da lei. A conquista, a manutenção e a defesa do poder é feita com recurso à violência, ao assassinato inclusive. A tese que proponho expor e defender neste artigo é que o poder da família Corleone não é um poder despótico, mas um poder altamente controlado, regulamentado por códigos de honra, de parentesco, de amizade. Isso por um lado, e por outro lado, que o exercício desse poder tem uma componente simbólica fortíssima, uma componente litúrgica como irei demonstrar.

\section{Palavras Chave:}

cinema - análise fílmica - narrativa - liturgia - O Poderoso Chefão

\begin{abstract}
:
The movie «The Godfather» (entitled «O padrinho» in Portugal, and «O poderoso chefão», in Brazil) is a «gangster» movie, about a Mafia family, about a power formed outside the law. The conquest, maintenance and defense of the power are done using the violence, including murder. The subject I propose to expose and defend in this article is that the Corleone's power is not a despotical one, but a highly controlled power, conducted by a code of honour, kinship, friendship. That's right for one hand, and otherwise, that the practice of this power has a strong symbolical component, a liturgical component, as I am going to demonstrate.
\end{abstract}

\section{Keywords:}

cinema - film analysis - narrative - lityrgy - The Godfather

\section{Os conceitos de poder e liturgia}

O filme "The Godfather" (intitulado "O padrinho", em Portugal, e "O poderoso chefão", no Brasil) é um filme de "gangsters", de uma família mafiosa, de um poder constituído fora da lei. A conquista, a manutenção e a defesa do poder é feita com recurso à violência, ao assassinato inclusive. Ora a tese que proponho expor e defender é que o poder da família Corleone não é um poder despótico, mas um poder altamente controlado, regulamentado por códigos de honra, de parentesco, de amizade. Isso por um lado, e por outro lado, que o exercício desse poder tem uma componente simbólica fortíssima, uma componente litúrgica como irei demonstrar.

O poder, como aqui o entendo, é uma relação entre quem manda e quem obedece. Mandar, por sua vez, significa impor. E disso se distingue de outros tipos de relação afins como pedir ou persuadir. Quem obedece é obrigado a obedecer. Obrigado como? Pela sanção e pela violência. Quanto maior for a capacidade de sanção e de violência tanto maior a capacidade de dar uma ordem, de levar à obediência de quem ouve e executa uma ordem. Ou seja, é uma noção restrita de poder a que uso aqui. Tem poder quem tem capacidade de impor, se necessário à força. 
A célebre "proposta irrecusável" de Don Vito Corleone - provavelmente uma das expressões mais marcantes do filme na história do cinema - é um exemplo claro de poder puro e duro. Quando Michael Corleone conta à namorada Kay Adams a proposta irrecusável que o pai fez ao manager do afilhado John Fontane é no sentido de mostrar o poder tremendo do chefe da família, onde a sanção é a mais radical, a morte de quem não acata um pedido/ordem. Nessa ocasião, Michael tem a necessidade de se demarcar desses métodos: "That's my family, Kay. Not me". E em que consistia tal "proposta irrecusável" que Vito Corleone fizera ao "manager" do afilhado John Fontane? A proposta era de que no fim do documento ou ficava a assinatura ou os miolos do interlocutor. Convém dizer que a proposta era feita com a pistola de Luca Brasi, um pistoleiro às ordens de Don Vito, encostada à cabeça do "manager".

Nesta acepção de poder não cabem as noções de imprensa como quarto poder, de poder simbólico, de poder da publicidade, e outros similares, que se inserem numa noção lata de poder, que inclui controlo social, condicionamento económico e influência política. Poder, como é entendido aqui, e repito, é a capacidade de impor algo a alguém com recurso à força se necessário. O poder mafioso é um poder violento. Mas é justamente a partir daqui, isto é, da definição restrita de poder e da constatação do poder mafioso como poder violento, que importa sublinhar o carácter litúrgico do poder da família Corleone.

O conceito de liturgia significa a objectivação de normas, formas, gestos, na execução de certas acções e comportamentos pertencentes ao culto religioso. A liturgia é um sistema estabelecido de ritos e simbologias, de cerimónias, que não de tipo subjectivo e disso se distingue da devoção. A devoção é particular, pode alterar-se sem mais, é de tipo sentimental, a liturgia é objectiva, pública, racional. Podemos dizer que a liturgia é uma língua do culto, e que, como qualquer língua, é social e imutável, para usarmos as categorias linguísticas de Saussure. A liturgia consubstancia as formas que determinada comunidade de crentes usa para rezar e praticar os actos que se prendem directamente com o exercício da fé. Neste sentido, pode dizer-se que a liturgia é a língua da fé, não só em palavras, mas também em gestos, actos e ritos. E como não existe uma língua individual, assim também não existe uma liturgia individual. Um crente não pode modificar a liturgia, tal como um falante não pode alterar a língua. Liturgia e língua são sistemas anteriores ao uso que deles se fazem. Não é que existam fora desse uso, mas transcendem, na sua estrutura e natureza, a ocasionalidade do uso. Louvar a Deus, pedir-lhe perdão, assume, pela liturgia, formas próprias, gerais e comuns a toda a comunidade de crentes. Formas essas ditadas pela própria divindade ou cristalizadas pela história da comunidade. Ou seja, não é à vontade do freguês. A liturgia significa justamente a norma geral e adequada de prestar culto (1).

Só há liturgia no seio de uma comunidade. Antes do mais, quer isto dizer que a liturgia é essencialmente eclesial e que não há uma liturgia individual. A liturgia é a expressão da fé da comunidade, a formulação conjunta e sistemática dessa fé. Aqui encontramos bem patente uma grande diferença entre o individualismo protestante e o comunitarismo católico. No protestantismo, em particular nas «low churches", a liturgia ocupa posição secundária, ao contrário da centralidade que assume na Igreja Católica.

A liturgia que facilmente se descobre em "The Godfather" é muito próxima da liturgia católica romana, como se vive e pratica nos países católicos do sul da Europa, em particular em Itália. Como tenho vindo a desenvolver, é, e não pode deixar de ser, uma liturgia comunitária, só que não eclesial, mas familiar. Em "The Godfather" a família é a comunidade que baliza o sentido e a acção de todos os indivíduos. Não há propriamente indivíduos, mas membros, ou seja, familiares, e mesmo os que não pertencem à família de sangue são integrados na família através da relação de padrinho e afilhado, de madrinha e afilhada.

O enredo do filme assenta na estrutura familiar e em objectivos familiares. O sujeito do filme não é Don Vito ou Michael mas sim a família Corleone. Eles são os chefes, mas a sua acção obedece aos interesses da família e pauta-se liturgicamente pelo espírito familiar. Não fosse a acção dos personagens integrada 
comunitariamente, não se poderia falar de um carácter litúrgico relativamente ao filme.

\section{Breve resumo da história do filme}

A história de «O padrinho" é em traços muito largos a seguinte. A coexistência mais ou menos pacífica das cinco famílias de Nova York: (Vito) Corleone, (Emilio) Barzini, (Phillip) Tataglia, (Anthony) Stracci, (Otílio) Cuneo, é posta em causa com o aparecimento de Sollozzo, o Turco, que conseguiu o apoio da família Tataglia e pretende a protecção legal da família Corleone para o negócio do narcotráfico, visto como o negócio do futuro. Face à recusa de Don Corleone de entrar no negócio das drogas, Sollozzo procura matar o Don e fazer com que o filho, Santino, faça um acordo com ele. Michael Corleone, o filho mais novo de Don Vito, que estivera fora dos negócios da família e fora até um herói no exército americano em combate na II Guerra Mundial, mata Sollozzo e um capitão da polícia nova-iorquina. Refugia-se na Sicília onde acaba por casar com uma jovem siciliana, Apolónia. Entretanto, a guerra desencadeada entre a família Corleone e as outras famílias, leva à morte de Santino Corleone e de Bruno Tataglia. "O padrinho" decreta então tréguas e reúne com os Dons de Nova Iorque e dos Estados Unidos para acabarem de vez com aquela guerra. Impõe como única condição que o filho Michael possa regressar à América sem quaisquer receios de ser acusado do homicídio do capitão da polícia e de ser morto.

Apercebe-se na reunião que por trás do ataque à família Corleone, no assassinato de Santino e no atentado na Sicília a Michael, que deixa ileso este, mas mata a mulher, estava Don Barzini.

A segunda parte do filme é a passagem do poder de Don Vito para Michael, Mike ou Mikey. A afirmação deste como Don, o chefe da família, não é fácil. Tem de se impor aos seus próprios familiares, nomeadamente ao irmão Fredo e aos «capos" Clemenza e Tessio. O objectivo de Michael é legalizar os negócios da família, em cinco anos como diz a Kay Adams a sua namorada inicial no filme, e sua segunda mulher, e deslocar as actividades da família de Nova York para Las Vegas. Avisado pelo pai de que os inimigos dos Corleone tentarão matá-lo a ele Michael através de um elemento íntimo da família, Michael dá-se conta, no funeral do pai, de que esse elemento é Téssio. O fim do filme então é o ajuste de contas final, a morte das cabeças das outras famílias nova-iorquinas. Michael acaba por ser reconhecido como verdadeiro padrinho, como Don Michael e o filme termina com Clemenza beijando a mão de Mikey, e chamando-lhe Don Corleone.

\section{Um acto de fé na América}

A cena inicial do filme começa com uma profissão de fé na América. Em minha opinião é um dos maiores começos de filme na história do cinema. Com a pantalha completamente escura, ouve-se uma voz com forte sotaque de imigrante italiano: «I believe in America". Só depois desta declaração no escuro é que o rosto de Bonasera começa a surgir lentamente da escuridão da pantalha, fazendo lembrar um retrato de Rembrand, com a luz incidindo na fronte e no rosto, sobre um fundo negro.

Todas as verdadeiras profissões de fé são feitas no início e no escuro. A força de um credo, nomeadamente o «credo in unum Deum", está na ausência absoluta de quaisquer outras referências além da fé. Quem crê não o faz na sequência de um processo ou menos ainda no fim de uma cadeia de causas e efeitos. Não se chega à fé por demonstrações, raciocínios ou conjecturas, antes a fé é um acto primeiro, espontâneo, causa incausada de tudo o que se segue. Na verdade, é estulto perguntar a alguém que faz uma profissão de fé, porque é que crê, quais as razões por que acredita. Pode-se sim perguntar o como, mas não o porquê, e isso justamente porque nada há atrás ou além da fé; tudo fica para diante, aquém. A fé interroga-se pelos frutos, por tudo o que dela provém, por aquilo que origina, provoca ou justifica. Antes da fé existe o escuro, a luz vem depois da fé.

$\mathrm{O}$ acto de fé na América com que começa o filme de Coppola «O padrinho" ilumina a ideia de América que baliza todo o enredo, que explica as peripécias, que justifica todas as acções dos personagens. O sotaque de 
imigrante revela que a América que se professa, é a América da imigração, a terra de uma nova vida, dos novos começos, de todas as possibilidades, em suma a réplica moderna da outra terra outrora prometida aos hebreus, a terra do leite e do mel. Uma e outra são terras de promessa e, «eo ipso", terras de fé.

A segunda frase na profissão de fé de Bonasera é o reconhecimento de que a América o tinha feito afortunado, «America hás made my fortune". A América em que com ele milhões de imigrantes ao longo de séculos acreditaram é a América que considera como verdade evidente o direito de todos à liberdade e à prossecução da felicidade. A fé na América é, ao fim e ao cabo, a fé no direito de cada um buscar a felicidade, para si e para os seus. É a partir daí que a acção se conforma consoante os princípios e as leis da nova terra. Porque acredita na América, porque a América lhe dera fortuna, Bonasera educa a filha à maneira americana, deu-lhe liberdade, «I raised my daughter in the american fashion. I gave her freedom".

A profissão de fé de Bonasera é, bem vistas as coisas, a profissão tácita de Don Vito Corleone. Também ele acredita na América, também a América o tornara afortunado, e também ele educa o filho Michael «in the american fashion". À primeira vista isto pode parecer um contra-senso. Como pode um fora-da-lei, um mafioso, acreditar na América? Não vive ele à margem, em negócios ilícitos, sempre em risco de ser julgado, condenado e metido na prisão? Porém, as acções e os negócios de Don Corleone e da família visam a legitimação dos mesmos e a integração na sociedade americana e no sistema de poder. O objectivo de Don Vito era que o filho Michael se tornasse um dia Senador Corleone. Esse objectivo, ou sonho, estava justamente fundado na fé na América. Ali todos podem subir e o filho de um emigrante pode atingir as maiores cargos sociais e políticos. Com efeito, é a fé na América que coloca lá no fundo entraves aos negócios das drogas, e que o Padrinho se recusa a fazer. É que esse negócio tornaria impossível essa integração social e política da família Corleone no seio da sociedade americana.

\section{A liturgia da cena inicial}

A cena inicial do filme dura perto de sete minutos e contrasta com a cena seguinte, a festa do casamento da filha de Don Vito. É uma cena passada no interior, a meia luz, de cores escuras, de palavras pausadas a «sotto voce", de silêncios, como se ocorresse num gabinete de um bispo. De vez em quando ouve-se vindo de fora a algazarra que se passa cá fora, no casamento. Lá dentro encontram-se apenas quatro homens, Don Vito Corleone, o filho deste, Santino, o conselheiro Tom Hagen e Bonasera.

Bonasera vem pedir a Don Corleone que lhe faça justiça. Afinal a América em que acredita, que o tornou um homem abastado, é uma América que não lhe faz justiça. Ou melhor, que não lhe faz justiça em sentido material (extremada na lei de Talião, olho por olho, dente por dente). Ele bem tentou agir como um bom americano: «I went to the police like a good American". Os tribunais pronunciaram-se, condenaram os rapazes que bateram na filha, mas essa justiça é unicamente formal, uma justiça de tribunais, mas que não aplica a justiça como Bonasera a entende no fundo do seu ser. Os que bateram na filha como se fora um animal, que a desfiguraram - tendo sido bonita, já não o voltaria a ser - são postos em liberdade naquele mesmo dia: «They went free that very day!", exclama indignado Bonasera.

Vem então apelar a Don Vito para que faça justiça, e por justiça nesse caso ele entende a morte dos dois rapazes. Pede-lhe que mande matar os dois rapazes. Só que Bonasera faz mal o pedido. A cena pode ser entendida como uma lição de liturgia, sobre as regras a observar e de como seguir os procedimentos correctos. «O padrinho" explica em pormenor a Bonasera como as coisas se fazem, qual a forma correcta de pedir. Com efeito, comete falhas graves, chegando mesmo a oferecer dinheiro a Don Vito como se fosse um assassino a soldo. Felizmente encontrou um Don Corleone pedagógico que não lhe fez pagar caro o erro.

Antes de mais e desde logo todo o episódio é de natureza litúrgica na medida em que o pedido de Bonasera tem uma cobertura institucional. O que pretendo significar com institucional é que as acções, os gestos, os 
significados, não são únicos, arbitrários, mas que se inserem numa regra que os institui, que lhes dá o verdadeiro significado. A instituição neste caso é a regra de que nenhum siciliano pode recusar um pedido no dia do casamento da filha. A enunciação da regra é feita por Tom Hagen na cena seguinte, quando justifica a sua ausência da festa. O filme mostra como outros além de Bonasera fazem uso desse costume. O dono de uma pizzeria (Nazorine) pede a ajuda do Padrinho (Chefão) para que este faça uso das suas influências e torne possível a permanência na América do seu ajudante e futuro genro (Enzo), o indivíduo que à noite visitará Don Vito Corleone no hospital e ajudará Michael a impedir o assassinato do pai. O pedido não aparece ao acaso, antes configura um caso. $\mathrm{O}$ aspecto litúrgico é a existência de uma regra, a definição de um momento próprio (o casamento da filha) para um determinado acto (o atendimento de um pedido).

Bonasera está então no seu direito de fazer o pedido de justiça. Mas o pedido é mal feito, não cumpre as regras devidas. Mal feito de um ponto de vista material e formal. Material porque quer a morte dos dois rapazes, e a filha não está morta, e Don Corleone faz-lhe notar isso. Bonasera corrige então essa parte: pede apenas que sofram como ela sofreu. Do ponto de vista formal, também faz erros, comete uma enorme desconsideração, pede que Don Vito Corleone faça justiça a troco de dinheiro, como se fora um simples bandido a quem se paga para fazer uma tarefa suja ("to murder for money").

A primeira reacção de Don Corleone não é sobre o conteúdo, mas sobre a forma: Porque é que Bonasera fora à polícia e não fora primeiro falar com ele? "Why did you go to the police? Why didn't you come to me first?". Don Corleone entende o modo de proceder de Bonasera: "I understand. You found Paradise in America. You made a good living, you had police protection, you had courts of law. You didn't need a friend like me". Mas a justiça real, a da equidade, ele não a encontrou nos tribunais americanos. É isso que procura agora junto de Don Corleone. Só que o faz de um modo desacertado, sem respeito: "But you don't ask with respect. You don't offer friendship. You don't even think to call me godfather”. Bonasera acha que é tudo uma questão material (matar, fazer sofrer de igual modo, pagar). «O padrinho" aborda porém a questão de um outro ponto de vista: formal, cerimonial. Porque é que Bonasera o trata com tão pouco respeito?

A questão formal, a questão litúrgica, tem prioridade sobre a questão material. Se Bonasera tivesse vindo como amigo: "If you had come to me in friendship", então sim, a questão material também seria resolvida: "That scum that ruined your daughter would be suffering this very day". É necessário fazer bem as coisas, uma a seguir às outras, oferecer amizade, chamar Padrinho a Don Vito Corleone. É a partir destes sinais, destes gestos que as coisas surtem efeito (os sacramentos na doutrina católica definem-se como sinais actuantes). Também aqui com Don Corleone o sacramento de celebrar amizade (chamar padrinho e beijar a mão) tem efeitos, e que efeitos: os teus inimigos serão os meus inimigos ("and then they will fear you").

É a partir desta lição de cortesia, de liturgia, de comunidade, que Bonasera cumpre finalmente o ritual: "Be my friend?" que, perante alguma relutância de Don Vito, é reforçado com o vocativo de Padrinho e com o beijo na mão. Só depois de feito o ritual, e bem feito, é que o Don Corleone se apresta a satisfazer o pedido que Bonasera lhe faz no dia do casamento da filha. Mas mesmo antes disso, o Padrinho ensina a Bonasera que a relação em que se envolvem é uma relação de reciprocidade, em que um dia precisará dos seus favores, então nessa ocasião irá receber o seu crédito que a feitura de justiça lhe proporciona agora.

Mas além da lógica própria dos procedimentos para fazer um pedido há também o cenário e o ambiente apropriado. Os pedidos são feitos no silêncio do gabinete de Don Corleone, onde as persianas descidas criam uma meia luz, criando a claridade dos rostos e a obscuridade dos ambientes, tal como no confessionário. Aliás Mário Puzzo realça esse ponto, de que o Padrinho ouvia como se fosse um confessor. Efectivamente, os gestos de Don Corleone quando Bonasera lhe sussurra ao ouvido a sua pretensão de que os dois rapazes sejam mortos são os gestos de um confessor, aliás no seguimento a descrição da cena narrada no livro de Mário Puzzo: "Depois, curvando-se de tal maneira que os seus lábios quase roçaram a orelha do patriarca, disse qualquer coisa ao ouvido de Don Corleone, que escutava tudo como um padre no confessionário, olhando 
para longe, impassível e distante".

A presença silenciosa do filho mais velho, Santino, e do "consigliere", Tom Hagen, empresta solenidade ao acto oficiado por Bonasera e Don Vito. Quando Don Vito se levanta, incomodado com a desconsideração de Bonasera ao perguntar quando era preciso pagar ("How much shall I pay you?"), também Tom Hagen se levanta e Santino se movimenta, como dois acólitos do patriarca. O movimento conjunto mostra a unidade da família, a primazia do chefe e o respeito e a obediência que o filho e o conselheiro lhe prestam.

\section{Os rituais familiares}

Joseph Ratzinger parte da definição de rito dada pelo jurista romano Pomponius Festus do segundo século para explicar o conceito de ritual ou rito, "mos comprobatus in administrandis sacrificiis" (2). Traduzo por "costume comprovado para administrar os sacrifícios". Ritual começa por ser um costume ou uma prática tradicional de fazer algo. Trata-se de fazer da mesma maneira ou de repetir o que outros já fizeram. Porquê? Porque essa forma ou maneira de fazer se revelou como boa. É um "costume comprovado", isto é, já deu provas de ser a forma adequada de fazer esse algo.

Crucial no conceito de ritual é a noção de repetição. Voltar a fazer é o princípio de ritual. Não há que inventar, há que fazer o que é suposto fazer. Joseph Ratzinger acrescenta que a "criatividade" não é uma categoria autêntica da liturgia. Com efeito, a liturgia assenta na tradição do que nos chegou desde os primórdios e que não cabe aos presentes modificar. Nada mais descabido do que tentar ser original na liturgia (3).

Em "O padrinho" os hábitos e as tradições são regras de conduta. Começo com um exemplo de uma cena pouco importante, mas muito significativa de um ponto de vista litúrgico, para mostrar como a família Corleone tem rituais que ordenam até as práticas mais comezinhas do quotidiano. Quando o padrinho, depois do atentado, regressa a casa e jaz deitado no andar superior, a família em baixo junta-se à mesa de jantar. $\mathrm{O}$ filho mais velho senta-se numa das cabeceiras da mesa e a mãe noutra. Santino começa uma conversa sobre negócios e Carlo Rizzo comenta. Connie lembra então que "o pai nunca falou de negócios à mesa diante das crianças". Carlo diz à mulher para se calar, ao que Santino avisa o cunhado para nunca mandar calar a irmã. Aí a mãe diz a Santino para não se meter entre os dois. Depois, quando Carlo se dirige a Santino e a Tom dizendo-lhes que gostaria de falar com eles a seguir ao jantar pois que poderia fazer mais pela família, é Santino que põe fim à conversa afirmando que "não se discutem negócios à mesa".

O modo de proceder do patriarca, de nunca falar de negócios à mesa, é invocado como uma forma correcta de proceder para todos os outros. Ou seja, não se trata de lembrar um hábito do pai, como se de característica própria se tratasse, trata-se sim de lembrar um hábito exemplar com força vinculativa para todos os outros. Todo o ser humano tem características próprias, não extensivas aos outros, como certas particularidades irrepetíveis por outros, sob pena de serem mimetismos cómicos. O hábito torna-se ritual quando se converte em regra vinculativa para todos os outros.

Por sua vez, a indicação da mãe a Santino para que não se meta é a aplicação da regra popular de que ninguém, nem mesmo um familiar tão próximo como um irmão, se deve meter nas relações entre marido e mulher. Assuntos de um casal são tratados dentro do casal. Entre marido e mulher não metas a colher. Veremos à frente como é o desrespeito a esta regra que leva Santino à morte. A liturgia é tanto mais admirável quanto ela se impõe por força própria.

A liturgia não é uma etiqueta, boas maneiras que alguém adquire no berço, e que arbitrariamente segue ou não segue. Na verdade o mais admirável no filme de Ford Coppola é o facto de a liturgia familiar se impor aos dois personagens centrais do filme contra a própria vontade destes. Michael Corleone é levado a assumir as 
funções de Don ao revés das suas intenções e, sobretudo, dos planos do pai, Vito Corleone. Michael repetirá os passos do pai forçado pelas circunstâncias e pelo desígnio da família, como se a isso estivesse condenado. Ele que no início diz à namorada que os métodos violentos de "propostas irrecusáveis" eram próprios da família e não dele, acaba no final, em Las Vegas, por declarar que tem uma proposta irrecusável para Moe Green.

Existem dois momentos no filme onde Don Vito expressa desânimo. O primeiro é quando depois do hospital regressa a casa e Tom Hagen, ao contar o se que passou depois do atentado, acaba por dizer ao Padrinho, a pedido deste, que fora Michael quem matara o Solozzo e o polícia. Sem poder falar o patriarca abana a cabeça em desalento profundo como quem vê os melhores planos e o sentido da sua vida desabarem por terra. Michael não estava destinado a ser um mafioso; tinha ido para a universidade, ingressara no exército americano e combatera na guerra, tinha uma namorada não-italiana, nunca entrara nos negócios escuros da família. Tinha assim todas as condições para iniciar uma carreira de sucesso na sociedade americana. Mas agora depois do duplo assassinato o sonho dessa carreira esfumava-se por inteiro. O pai tudo fizera para o afastar do meio mafioso e o destino acabava por o puxar para o âmago da família e das suas guerras.

O segundo momento de desânimo é quando tem no jardim a última conversa com Michael, já depois da transferência do poder. Por trás da preocupação quase obsessiva com Barzini que, em sua opinião, irá tentar matar Michael, o velho Don não consegue dissimular uma enorme tristeza e resignação, de tal modo que Michael lhe pergunta, que tem e que o preocupa: "What's the matter? what's bothering you?". É então que Vito Corleone confessa os seus planos e o seu fracasso: Nunca quisera aquilo para o filho: "I never wanted this for you", que quando chegasse a altura de Michael: "I thought that when it was your time", seria este a mexer os cordelinhos: "You would be the one to hold the strings", como "Senador Corleone ou Governador Corleone. Something". E remata esta confissão, onde revela os planos profundos da sua vida, com o lamento amargo de que não houvera tempo suficiente: "Just wasn't enough time. Wasn't enough time". Porém, Michael responde que lá chegarão: "We'll get there, Pop... We'll get there". O pai diz duas vezes que não houvera tempo e o filho repete duas vezes que lá chegarão, como se oficiasse uma cerimônia religiosa.

Depois de matar Solozzo e o capitão da polícia, Michael Corleone refugia-se na Sicília. O filho regressa às origens do pai. Nas terras secas e pobres dos antepassados conhece os códigos de honra ancestrais que regulam a vida das famílias. Em termos bíblicos é como se o assassinato fosse a entrada baptismal na comunidade mafiosa e a Sicília fosse o deserto em que Michael se prepara para as suas funções nos negócios da família. Antes da Sicília Michael era um jovem americano, com diploma universitário, depois da Sicília Michael torna-se um "homem de honra" com a missão de defender os interesses familiares. Claramente o episódio da Sicília divide o filme em duas partes. A primeira parte é o período "civil" de Michael, período em que pensa o futuro em função dos seus interesses individuais. A segunda parte é o período "mafioso", em que se submete, a si e aos seus - a família mais próxima, mulher e filho -, ao futuro da família Corleone.

\section{Os pecados litúrgicos}

A liturgia de hábitos, de comportamentos, comanda o modo de acção da família no interior e para o exterior. Internamente a família é uma comunidade de solidariedade total entre todos os seus membros incluindo mulheres e crianças. Umas das características mais marcantes do filme é o ambiente familiar de muitas das suas cenas, com a presença das mulheres e das crianças da família. É um ambiente familiar, alegre e festivo (aquando do casamento de Connie), afectuoso (quando Don Vito regressa do hospital e é cumprimentado por toda a família, em particular os netos), terno (quando o Padrinho brinca com o neto no jardim, imediatamente antes de morrer). Desse ambiente familiar são afastadas as preocupações de negócios. Isso é tarefa dos homens e só dos homens. É o próprio Don Vito que o diz ao filho na última conversa. As mulheres e as crianças podem viver despreocupadas, mas não os homens: "Women and children can be careless, but not men". Externamente a família trava continuamente uma luta pela sua sobrevivência económica. É um assunto 
exclusivo de homens. Nas cenas finais do filme, Michael expressa isso muito claramente à mulher. Quando Kay lhe faz por duas vezes a pergunta se é verdade (que foi ele a ordenar o assassinato do cunhado Carlo), por duas vezes Michael lhe diz com veemência que nunca, mas nunca o questione sobre os negócios da família (e o negócio neste caso é saber se é verdade: "Don't ask me about my business". Daquela vez vai abrir uma excepção. Mas a resposta é uma mentira. Em termos litúrgicos justifica-se, contudo, tal mentira pois que Kay não pode ter acesso a qualquer informação do mundo dos negócios, mundo exclusivo dos homens. Há uma separação radical entre os dois mundos, o familiar e o dos negócios. É um dos princípios basilares dos códigos e da liturgia dos homens de honra.

Na acção externa a família fala a uma só voz. Este é também um dos preceitos essenciais do seu agir. É justamente por Santino pecar contra este preceito que a infelicidade se abate sobre a família Corleone. Analisemos a cena do encontro com o Solozzo.

O encontro com Solozzo reveste-se de solenidade. É preparado por uma reunião informal entre Don Vito, Santino e o "consigliere" Tom Hagen. O padrinho pergunta-lhes a opinião e os dois são favoráveis ao negócio com Solozzo, um negócio que envolve drogas, o negócio do futuro (segundo Tom Hagen) e que envolve montes de dinheiro (segundo Santino). O padrinho apenas ouve e à pergunta directa de Santino sobre qual vai ser a resposta, reserva esta para a reunião com Solozzo. Este é recebido por Santino no topo das escadas e de seguida entra na sala onde cumprimenta Tom Hagen, Clemenza, Fredo, Tessio e finalmente Don Vito. Todo o estado maior da família Corleone se encontra na reunião. O ambiente é de cerimónia, pela envolvência - não é no gabinete de casa da família, mas no escritório da firma Genco -, pelos trajes, e pela disposição dos intervenientes. Rodeado pelos filhos (4), "capos" e conselheiro, Don Corleone ocupa o centro frente a Solozzo.

Apenas ele fala com Solozzo. Os outros assistem em silêncio e respeitosamente. É então que Santino quebra o curso litúrgico da cerimónia e intervém. De imediato Don Vito interrompe o filho: "Wait a minute". A falha grave de Santino num momento solene da negociação causa enorme constrangimento, como é visível nos primeiros planos dos rostos de Clemenza e de Tom Hagen. O rosto de Solozzo mais do que constrangimento demonstra que vê algo que não era suposto ver. A falha de Santino não pode passar desapercebida e sem comentário. Don Vito como que pede desculpa a Solozzo pela insensatez de Santino, atribuindo a culpa a si próprio por não educar bem os filhos: "I have a sentimental weakness for my children, and I spoil them, as you see. They talk when they should listen". Mas logo no final da reunião Don Vito admoesta Santino com severidade, intimando-o a nunca voltar a dizer a ninguém o que pensa: "Never tell anybody outside the family what you are thinking again".

Justamente por Solozzo se ter apercebido da opinião de Santino, que engendra o plano de matar Don Vito a fim de mais tarde negociar com Santino, como declara expressamente - "Sonny was hot for my deal, wasn't he?" - a Tom Hagen e ao próprio Michael. A quebra cerimonial de Santino constitui assim como que o pecado original causador dos sofrimentos da família Corleone, ao atentado ao pai, à sua própria morte, ao desabamento dos projectos familiares de Don Vito, ao degredo e ao fim dos planos pessoais de Michael.

A segunda falha litúrgica de Santino é o desrespeito à privacidade da vida conjugal da irmã. Intromete-se em assuntos pessoais onde não é chamado. Connie ela mesma tenta evitar que Santino se intrometa, bata no marido, e infrinja códigos ancestrais da intimidade do casamento. Tenta esconder de Sonny as marcas de violência, mas quando o não consegue, tenta assumir as culpas: "It was my fault!", dizendo que foi ela que começou a briga e repetindo sempre que a culpa foi dela: "Sonny, please. It was my fault. I hit him... I started a fight with him. Please, Sonny". Santino não corresponde ao pedido da irmã e sova o cunhado. Ora a cilada montada a Santino e que o leva à morte baseia-se justamente na falta de respeito pelo casamento da irmã. A briga conjugal entre Connie e Carlo Rizzie é encenada por parte deste e a comando da família Barzini, 
justamente para levar Santino a descurar os cuidados de segurança.

Santino nunca se preocupou com os princípios litúrgicos e Don Vito designa-o "a posteriori" como um mau Don: "I thought Santino was a bad don...". A chefia da família não se reduz a tomar decisões, a empenhar-se ao máximo, mas reside também em cumprir e fazer cumprir os preceitos de gestos, atitudes e símbolos que ordenam a vida em comum.

A falha cerimonial de Santino de não respeitar a voz única da família é também a falha de Fredo Corleone em Las Vegas. Também aí durante as negociações de Michael com Moe Green se intromete, mostrando uma divisão familiar. Depois de Moe Green sair e ficarem em família, Michael avisa Fredo de que, não obstante gostar dele como irmão, nunca, mas nunca, volte a tomar o partido de alguém contra a família: "You're my older brother, and I love you. But don't ever take sides with anyone... against the family again... ever". A repreensão é feita depois da reunião, já em privado, tal como Don Vito tinha feito com Santino.

O que temos aqui é a repetição de um gesto, melhor, de um método de proceder. Michael segue as pisadas do pai e ao fazê-lo retoma e confirma toda uma tradição de actuar. É o poder litúrgico que se funda não só directamente na capacidade de agir, mas também na força simbólica que lhe advém de se enquadrar num ritual de acção. A repetição cria um hábito e um hábito cria uma regra. E quem tem regras tem instrumentos de acção para os desafios que tão imprevisivelmente quanto inevitavelmente se colocam no dia a dia de quem exerce o poder.

\section{Sobreposição litúrgica}

Uma das cenas mais memoráveis do filme é o assassinato dos outros Dons de Nova Iorque, já quase no final do filme, cena entrecuzada com o baptismo do afilhado de Michael Corleone. Enquanto decorre o baptismo do novo membro da família Corleone, decorre a operação de limpeza de sangue dos seus inimigos. A cena eclesial é solene, mas sem pompa. A língua litúrgica é o latim, que os presentes certamente não entendem, mas que infunde respeito. Os rituais baptismais têm sentidos precisos, que parece se estendem às acções violentas em curso, ordenadas pelo padrinho da criança. $\mathrm{O}$ padre sopra sobre a criança e com isso significa a expulsão dos maus espíritos, coloca-lhe sal na língua, e indica o poder de preservação do baptismo e o gosto pela sabedoria da igreja, unge com óleo a fronte da criança fazendo dela um eleito e um soldado de Cristo. O que chama a atenção é a cadência de palavras e de gestos; nada apressa a cerimónia religiosa, mas também nada a detém. A comunidade eclesial celebra baptismos há muitas centenas de anos, nas mais diferentes partes do mundo, a milhões e milhões de crianças, numa cerimónia que se repete em milhares e milhares de igrejas. O que distingue este baptismo é que se sobrepõe a uma cerimónia paralela, que não é tradicional, antes se distingue pela audácia de algo nunca antes feito, visto ou sequer pensado.

A mesma cadência litúrgica é a que comanda os preparativos da assassínio dos Dons. Apesar da novidade da acção que têm pela frente os homens às ordens da família Corleone executam os gestos, o vestir-se, o pegar nas armas, com a segurança semelhante à do padre oficiante do baptismo. Essa semelhança é trazida á superfície graças ao cruzamento de cenas, dentro e fora da igreja. A sincronia é perfeita. A cerimónia litúrgica encaminha-se para o seu auge com a profissão de fé, onde se passa ao vernáculo. O ministro pergunta: "Michael, crês em Deus todo poderoso?". E o padrinho Michael responde pelo afilhado Michael: "Creio". Na fé está a comunhão e a força da comunidade. Enquanto Michael professa em nome do afilhado as verdades da Igreja, lá fora os seus homens chegam aos locais prontos a entrar em acção. Estão calmos, não se denota qualquer nervosismo. Há tempo, pelo menos tempo suficiente para dentro da Igreja o padre rezar o Pai-Nosso, colocar a estola sobre a criança e dizer: "Entra na Igreja de Deus - 'ingredere in templum Dei"”, e proclamar o Credo. É ao som da proclamação das verdades da fé que vemos os soldados da família Corleone dar os últimos passos antes de começarem a disparar. $\mathrm{O}$ cruzamento de cenas é tremendamente feliz porque durante as cenas fora da Igreja mantém-se o som do que se passa dentro da igreja, as palavras do oficiante, o choro da 
criança e a música do órgão, como sons de fundo. É aliás a música do órgão que vai subindo, anunciando o auge, o clímax da acção. De repente o órgão pára, o rosto de Michael aparece num grande plano e é em silêncio que o padre, novamente em vernáculo, pergunta: "Michael Francis Rizzi, do you renounce Satan"? renuncias a Satanás? Antes da resposta de Michael, muda a cena para fora, o órgão inicia uma fuga forte, e vê-se Clemenza disparar a espingarda contra o primeiro Don. De novo, voltamos à igreja para ver Michael Corleone responder pelo afilhado: "Renuncio - I do renounce him", para de seguida vermos, na mudança de cena, Moe Green ser assassinado na maca da massagem.

E o padre pergunta: "E às suas obras... e às suas pompas?", e no espaço das perguntas e das respostas dentro da igreja os outros Dons nova-iorquinos são mortos lá fora. Só depois da limpeza do "bad blood" vem a pergunta sacramental: "Michael Rizzi, will you be baptized?", e Michel Corleone responde: "I will", e com o assentimento a criança recebe a água lustral em nome do Pai, do Filho e do Espírito Santo que a liberta de todo o pecado, a torna filha de Deus e a converte num novo membro da Igreja. Depois de passarem em flash, pelo ecrã, os cadáveres dos dons assassinados, o padre dá a paz ao novo fiel e finaliza a cerimónia: "Michael Rizzi, go in peace... And may the Lord be with you. Amen".

\section{Conclusão}

No início defini "poder" como a capacidade de dar uma ordem e de a fazer cumprir. Max Weber identificou três tipos puros de poder legítimo, o legal ou racional, o tradicional e o carismático. O poder presente em "O padrinho" é claramente o poder tradicional, que Max Weber exemplifica da seguinte maneira: "O tipo mais puro é a dominação patriarcal". Obedece-se à pessoa por força da sua dignidade própria, santificada pela tradição, por piedade. O conteúdo das ordens é vinculado pela tradição, cuja violação inconsiderada por parte do senhor poria em perigo a legitimidade do seu próprio poder, que assenta apenas na sua santidade. Criar um novo direito em face das normas tradicionais surge, em princípio, como impossível”.

O poder neste caso assenta em normas tradicionais que se sobrepõem a eventuais caprichos de quem manda. O patriarca não é, assim, um déspota que ordena a seu belo prazer. Quem obedece reconhece no patriarca a autoridade para mandar e se fazer obedecer. Sem esse reconhecimento, que, no fim de contas, é o respeito, não há poder tradicional. A um tirano ou a um déspota obedece-se por medo, mas a Don Vito Corleone os seus "capos" e homens de honra obedecem por respeito. É verdade que fora da família ele é temido, e esse é também o objectivo do exercício do poder, mas dentro da família o chefe faz valer a sua autoridade pelo respeito que infunde.

O que a liturgia faz é dar expressão a esse respeito, nas duas vertentes: activa, dar-se ao respeito; e passiva, respeitar. Beijar a mão é um gesto de respeito, de inclusão na família, de obedecer às ordens, de ligar o seu destino pessoal ao desígnio colectivo da família.

Na primeira cena do filme, a do pedido de Bonasera a Don Vito para que lhe faça justiça, temos o gesto de beijar a mão. Na última cena, a da reconhecimento definitivo do novo Don da família, vemos Clemenza a beijar a mão a Michael Corleone e a chamar-lhe Don Corleone. Quando Michael ainda era um civil ("civilian"), na designação do próprio Clemenza, vemos este a tratá-lo como um menino ou rapazola, "hey Mickey", a meter-se com ele, porque não diz à namorada que a ama, a ensinar-lhe como fazer um molho de tomate para spaguetti. No final do filme vemos a tratá-lo como Don e a mostrar-lhe o devido respeito. Mudou a atitude de Clemenza como simultaneamente mudou a maneira de estar e de agir - e de vestir - de Michael Corleone. O jovem despreocupado do início do filme tornou-se um jovem chefe preocupado na segunda parte do filme, assumindo o peso da responsabilidade em assegurar a continuação da família Corleone como instância de poder. Na primeira e na última cena temos o mesmo gesto "o beijar da mão". A sala é a mesma. O significado é o mesmo. Mas os intervenientes são diferentes. A liturgia está na salvaguarda das formas e do 
seu significado.

Termino com mais um empréstimo da doutrina cristã. No catolicismo existe o conceito de carisma do ministério. Quer isto dizer que uma determinada posição ou função dentro da igreja é revestida de um carácter especial, de uma assistência divina particular para aquele lugar. Um bispo, pelo facto de ser um bispo, goza do carisma do seu ministério. Não é mais o Pe. João, Pe. José, ou Pe. António, é um bispo, um sucessor dos apóstolos. Assumiu uma função dentro da igreja e o seu estatuto alterou-se por força da assistência divina de Cristo à sua igreja. Michael Corleone ao ser reconhecido como padrinho passa a gozar desse carisma ministerial. Já não é mais o Michael ou Mickey, mas Don Corleone.

Falar de liturgia hoje é algo "demodé", antiquado. Com efeito, a liturgia é formal, consiste em formalidades. Ora os tempos são de informalidade e regras e fórmulas são encaradas como algo obsoleto, que não tem mais lugar nos tempos que correm. Os jovens vestem-se qualquer maneira, vão de shorts para a aulas, e as mulheres vão de alças à missa, os adultos tentam acompanhar os jovens nessa informalidade e abandonam as regras de conduta que lhes foram transmitidas pelos pais. Informalidade no vestir, informalidade no agir, informalidade nos tempos: come-se a qualquer altura, na cozinha, quarto, sala de estar ou na rua, informalidade nos espaços: as casas convertem-se em estúdios e a sala é simultaneamente sala, quarto e cozinha.

A liturgia consagra uma especificidade de tempos e de espaços, criando tempos próprios e espaços dedicados. Comer a horas próprias, com rituais próprios, em lugares reservados, faz de um gesto trivial, vegetativoanimal, uma cerimónia, reveste esse acto de uma solenidade que em si não tem. A liturgia são as palavras, os gestos que dão contornos de sentido às vivências humanas, nomeadamente às colectivas. Sem liturgia o viver social arrisca-se a ser um todo informe, sem contornos definidos, onde os indivíduos se perdem, sem saber o norte e o sul. A criação divina no livro do Génesis transforma o caos em cosmos. Cria as formas originais, o sol, a lua, a terra, os mares, os dias e as noites. O mundo ganha formas e torna-se o mundo onde o homem é colocado como coroa da criação. A liturgia converte o caos em cosmos social e colectivo. A tirar uma lição do filme "O padrinho" é a de que a liturgia dá forma e sentido ao viver social e ao poder que inevitavelmente o habita.

\section{Notas:}

(1) Sobre o conceito de liturgia ver Romano Guardini, The Spirit of Liturgy (disponível na internet) e Joseph Ratzinger, Der Geist der Liturgie. Eine Enführung, Freiburg: Herder, 2006.

(2) “Ritus definiert als 'bewährten Gebrauch in der Verwaltung der Opfer””, ibidem, p. 137.

(3) "In die Liturgie gehört solche Art von Schoepfertum nicht hinein. Sie lebt nicht von den Einfällen des einzelnen oder ingendwelcher Plannungsgruppen", ibidem, p. 145.

(4) Michael não se encontra na reunião, pois nesse momento não pertence ao "business" da família, ou melhor, é um "civilian", o seu estatuto dentro da família era do mesmo género do das mulheres e das crianças, "careless".

\section{Mini Currículo :}

Professor doutor e pesquisador em Ciências da Comunicação na Universidade da Beira Interior (Portugal). Diretor do Laboratório de Comunicação Online (Labcom) e Fundador da Biblioteca de Ciências da Comunicação (BOCC) e do jornal Urbi et Orbi. 


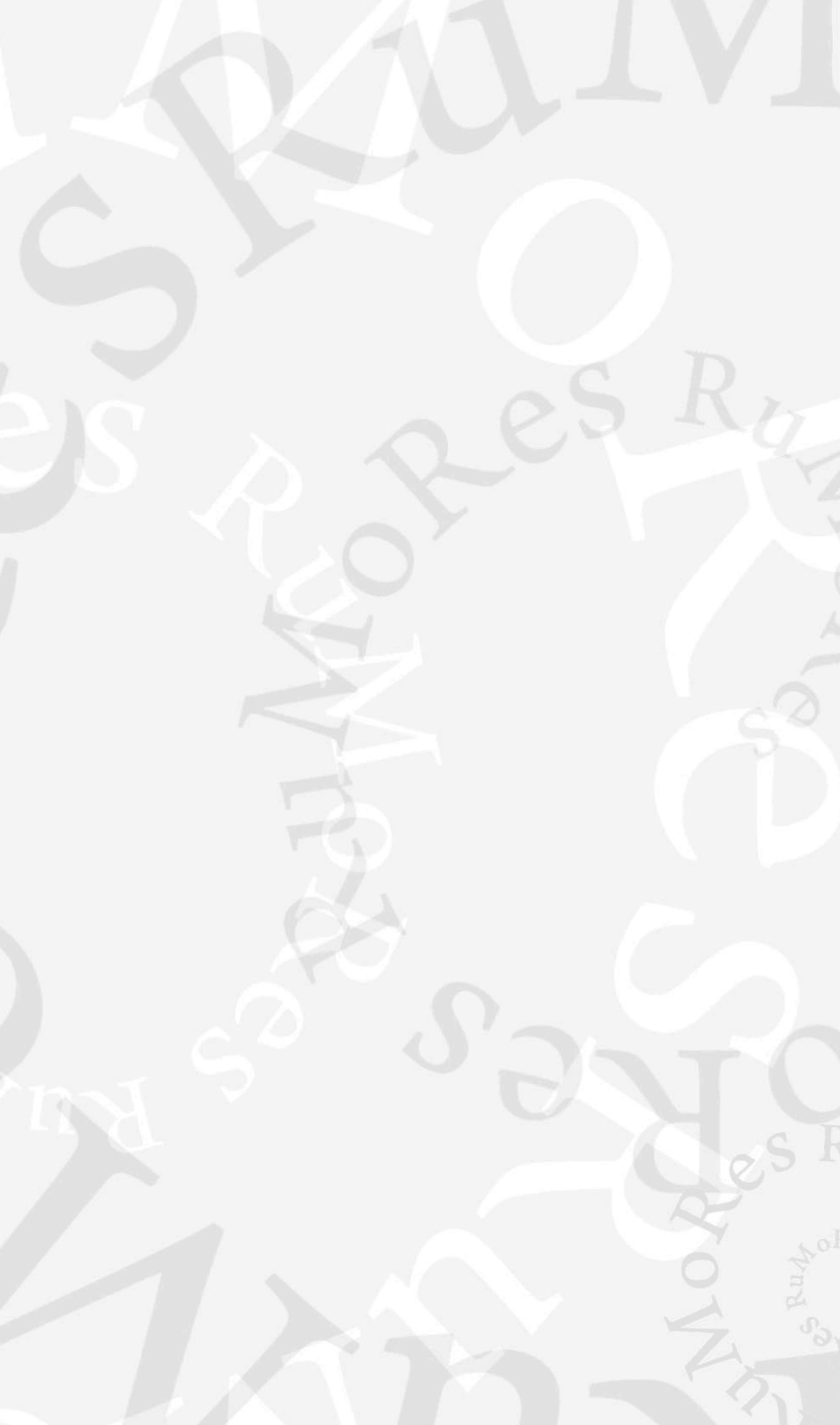

